\title{
The effect of zearalenone on PSII photochemical activity and growth in wheat and soybean under salt $(\mathrm{NaCl})$ stress
}

\author{
Janusz Kościelniak • Agnieszka Ostrowska • Jolanta Biesaga-Kościelniak • \\ Władysław Filek • Anna Janeczko $\cdot$ Hazem Mohamed Kalaji $\cdot$ Katarzyna Stalmach
}

Received: 26 November 2010/Revised: 29 March 2011/ Accepted: 15 April 2011/Published online: 5 May 2011

(C) The Author(s) 2011. This article is published with open access at Springerlink.com

\begin{abstract}
The effects of mycotoxin zearalenone (ZEN) on the photochemical activity of photosystem II (PSII) in wheat and soybean leaf discs incubated in ZEN solutions as well as the after-effects of pre-sowing soaking of seeds in solutions containing ZEN on the photochemical activity of PSII and on the seedlings growth under salt stress $(\mathrm{NaCl}$ solutions were investigated). The incubation of wheat leaf discs in ZEN solutions strongly inhibited the energy flux per cross section (CS) for absorption (ABS/CS), trapping (TRo/CS) and electron transport (ETo/CS), while the effects of ZEN action on soybean discs were opposite and the values of those parameters significantly increased with the increase in ZEN concentration. Incubation of seeds in a ZEN solution resulted in an increase in photochemical efficiency of PSII in soybean seedlings, but did not induce any response of PSII in those of wheat at medium illuminations. Only at the stronger illumination for both species did ZEN induce an increase in efficiency of excitation energy capture by open PSII reaction centers, photochemical quenching of chlorophyll $a$ fluorescence and quantum yield of PSII electron transport. Pre-sowing
\end{abstract}

Communicated by Z. Gombos.

J. Kościelniak ( $₫) \cdot$ K. Stalmach

Department of Plant Physiology, University of Agriculture

in Krakow, Podluzna 3, 30-239 Kraków, Poland

e-mail: j.koscielniak@ur.krakow.pl

A. Ostrowska · J. Biesaga-Kościelniak · W. Filek · A. Janeczko Institute of Plant Physiology, Polish Academy of Sciences,

Podluzna 3, 30-239 Kraków, Poland

H. M. Kalaji

Department of Plant Physiology, Warsaw University of Life

Sciences SGGW, Nowoursynowska 159 ,

02-776 Warsaw, Poland soaking of seeds in a ZEN solution decreased the photoinhibitory injuries of PSII in wheat and soybean due to safe scattering of the excess excitation energy through an increase in energy-dependent quenching (qE) and state transition quenching (qT). ZEN when added to $\mathrm{NaCl}$ solutions during the period of germination contributed to reduction in the growth inhibition of wheat seedlings. The incubation of wheat leaf discs in ZEN solutions strongly inhibited CS, ABS/CS, TRo/CS and ETo/CS. Possible effects of ZEN on some physiological processes in plants have been discussed especially in the context with photochemical activity of PSII and a salt stress.

Keywords Chlorophyll $a$ fluorescence · Germination . Photosystem II · Photoinhibition · Salinity stress $(\mathrm{NaCl})$. Soybean $\cdot$ Wheat $\cdot$ Zearalenone
Abbreviations
ABS Absorption energy flux
CS Excited cross-section of leaf
DIo Dissipation energy flux at the level of the antenna chlorophylls
ETo Flux of electrons from $\mathrm{Q}_{\mathrm{A}}^{-}$into the electron transport chain
Fm Maximum fluorescence in dark-adapted state
$\mathrm{F}^{\prime} \mathrm{m}$ Fluorescence when all PSII reaction centers are 'closed' in light-exposed leaves
Fo Initial fluorescence during the dark-adapted state
$\mathrm{F}^{\prime} \mathrm{O} \quad$ Fluorescence in leaves previously exposed to light; darkened just before measurement
$\mathrm{F}^{\prime} \mathrm{v} / \mathrm{F}^{\prime} \mathrm{m} \quad$ Efficiency of excitation energy capture by open PSII reaction centers
qN Non-photochemical quenching of chlorophyll $a$ fluorescence 
OEC Fraction of $\mathrm{O}_{2}$ evolving centers PSII in comparison to the control sample

PFD Photon flux density

PSII Photosystem II

$\mathrm{Q}_{\mathrm{A}} \quad$ The first stable electron acceptor in PSII

$\mathrm{qE} \quad$ Energy-dependent quenching

qI Photoinhibitory quenching

qP Photochemical quenching of chlorophyll

$a$ fluorescence

qT State transition quenching

RC Number of active reaction centers in the state of fully reduced PSII reaction center of PSII

TRo Excitation energy flux trapped by RC and utilized for the reduction in $\mathrm{Q}_{\mathrm{A}}$ to $\mathrm{Q}_{\mathrm{A}}^{-}$

Zearalenone 2,4-Dihydroxy-6-(10-hydroxy-6-oxo-trans1-undecenyl)-benzonic acid lactone].

$\Delta \mathrm{Fm}=\quad \mathrm{F}^{\prime} \mathrm{m}-\mathrm{Fs}$

$\Phi_{\text {PSII }} \quad$ Quantum yield of PS II electron transport

Yo Osmotic potential

\section{Introduction}

Zearalenone [ZEN, 2,4-dihydroxy-6-(10-hydroxy-6-oxotrans-1-undecenyl)-benzonic acid lactone] is well known mycotoxin because of its harmful effects on animals fed with fodders obtained from plants that were infected with fungi belonging to genus Fusarium. It was isolated for the first time from a fungal culture Gibberella zeae by Stob et al. (1962). Christensen et al. (1965) also isolated this substance and named it F-2. ZEN has a strong estrogenic activity due to its competition with $\beta$-estradiol in the binding to cytosolic estrogen receptors (Olsen 1989). ZEN estrogenicity causes several physiological alternations in the productive tract in animals (Price et al. 1993; Etienne and Dourmad 1994). Studies revealed that ZEN induces reactions at many levels of animal cell organization (Hassen et al. 2007). It was revealed that ZEN can be also toxic for plants causing chromosome damages and disorders in the synthesis of photosynthetic pigments (Kumar and Sinha 1995) as well as in photosynthesis and growth processes (Kościelniak et al. 2009). On the other hand, it was found that ZEN was an endogenous regulator controlling plant development (Meng et al. 1992), but as yet the mechanism of its action has not been explained. A peak of endogenous ZEN levels occurred during the vernalization of many winter plants, and exogenous ZEN applied at low concentrations could partly replace the low temperature requirement for ear development in winter wheat $(\mathrm{Fu}$ and Meng 1994; Fu et al. 2000; Biesaga-Kościelniak 2001;
Biesaga-Kościelniak and Filek 2010). ZEN can increase the number of ears, pods and seeds in wheat and soybean (Biesaga-Kościelniak et al. 2006a, b). It can also affect plant growth and development in many ways, as well as in the status and functioning of the photosynthetic apparatus (Kościelniak et al. 2009). The response of the photosynthesis process to ZEN and the participation of ZEN in the response of plants to environmental stress are less known. The aim of our study was to investigate the effect of ZEN on: (1) the photochemical activity of photosystem II (PSII) of wheat and soybean plants, (2) the photoinhibition of the photosynthetic apparatus, and (3) the growth of seedlings under salt $(\mathrm{NaCl})$ stress.

\section{Materials and methods}

Plant material and seedlings growth

The experiment was carried out on Polish common wheat (Tritium aestivum L.) cv. Torka and on soybean (Glycine $\max (\mathrm{L}$.) Merrill) $c v$. Aldana. Seeds were soaked for $24 \mathrm{~h}$ in the solution of ZEN (Sigma, Poznan, Poland) at a concentrations of $0.25,2.0$ and $4.0 \mathrm{mg} \mathrm{dm}^{-3}$, as similar to that were applied by Biesaga-Kościelniak (Biesaga-Kościelniak 1998, 2001; Biesaga-Kościelniak et al. 2003, 2006a, b), and separately in water (control). Plants were grown in growth rooms in $5 \mathrm{dm}^{3}$ pots filled with a mixture of clay, peat and sand $(3: 2: 1, v / v / v)$ at a 16-h photoperiod, PFD of $500 \mu \mathrm{mol}$ (quantum) $\mathrm{m}^{-2} \mathrm{~s}^{-1}$ (provided by high pressure sodium lamps, $400 \mathrm{~W}$; Philips SON-T AGRO, Brussels, Belgium) and at $50-60 \%$ of air humidity. During germination (5 days), a temperature of $25^{\circ} \mathrm{C}$ and that of $25 / 17^{\circ} \mathrm{C}$ (day/night) after emergence was kept. Seedlings were watered and fertilized with half diluted Hoagland nutrient solution as required (Hoagland and Arnon 1938).

Seed germination under salinity $(\mathrm{NaCl})$ stress condition

Wheat and soybean seeds were germinated on Petri dishes with different amounts of $\mathrm{NaCl}$ and ZEN. The osmotic potentials of $\mathrm{NaCl}$ solutions were: $0.00,-0.25,-0.50$ and $-1.00 \mathrm{MPa}$ (Chirife and Resnik 1984). ZEN solutions (0.0, $0.25,2.0,4.0 \mathrm{mg} \mathrm{dm}^{-3}$ ) were prepared using those with different $\mathrm{NaCl}$ concentrations. To avoid an increase in the solution concentration, Petri dishes with germinating seeds were kept at about $100 \% \mathrm{RH}$ and the solutions in the Petri dishes were changed every 2-3 days. Germination was carried our for 7 days for wheat and 10 days for soybean at $26^{\circ} \mathrm{C}$ under weak illumination $(80 \mu \mathrm{mol}$ (quantum) $\mathrm{m}^{-2} \mathrm{~s}^{-1}$ ). The dry weight (drying at $75^{\circ} \mathrm{C}$ ), and the length of the coleoptile and roots were estimated. 
The direct effect of ZEN on the photochemical activity of PSII

Leaf discs $(\varnothing 5 \mathrm{~mm})$ were cut out from the first (soybean) and third (wheat) leaf 3 weeks after the germination of seeds and incubated in water without ZEN for $72 \mathrm{~h}$. The discs were then placed in aerated vessels filled with a mineral nutrient medium (Appenroth et al. 1996) supplemented with ZEN at concentrations $0,0.5,1.0$ and $2.0 \mathrm{mg} \mathrm{dm}^{-3}$, chosen on the basis of previous experiments (Biesaga-Kościelniak 2001). The discs were soaked in ZEN solutions for $72 \mathrm{~h}$, at $20^{\circ} \mathrm{C}$, and at PFD $150 \mu \mathrm{mol}$ (quantum) $\mathrm{m}^{-2} \mathrm{~s}^{-1}$. Before measuring the fluorescence, discs were dried and adapted to darkness for $30 \mathrm{~min}$ (clips with a 4-mm diameter hole). The measurements of $\mathrm{Chl}$ $a$ fluorescence were carried out with a Plant Efficiency Analyzer (PEA; Hansatech Ltd. Kings Lynn, UK) with an excitation irradiance of $3 \mathrm{mmol} \mathrm{m}^{-2} \mathrm{~s}^{-1}$ (peak $650 \mathrm{~nm}$ ). Before measurements, the LED-light source of the fluorometer was calibrated using an SQS light meter (Hansatech Ltd. Kings Lynn, UK). Fluorescence intensity was measured with a PIN-photodiode after being passed through a long-pass filter. Changes in fluorescence were registered during irradiation of $10 \mu \mathrm{s}$ to $1 \mathrm{~s}$. During the initial $2 \mathrm{~ms}$, data were collected every $10 \mu$ s with 12-bit resolution. After this period, the frequency of measurements was reduced automatically. On the basis of these measurements, parameters: ABS/CS, TRo/CS, ETo/CS, DIo/CS and OEC were calculated based on the theory of energy flow in PSII and using the JIP test (Srivastava and Strasser 1977; Strasser and Strasser 1995; Lazár 1999; Lazár and Pospísiil 1999; Strasser et al. 2000; Appenroth et al. 2001).

The after-effect of ZEN on the photochemical activity of PSII in seedlings

Measurements of Chl a fluorescence were carried out at two developmental stages: after the development of the second and fourth leaves. Seedlings developed from seeds soaked in ZEN $\left(4 \mathrm{mg} \mathrm{dm}^{-3}\right)$ solution and water (control) was tested. The measurements were carried in the middle part of well-developed leaves situated at the highest part of the plant. The leaves were illuminated for a period longer than 5 min until stabilization of fluorescence. Photochemical measurements were made with an FMS2 fluorometer (Hansatech Ltd. Kings Lynn, UK). The source of the modulation beam (duration pulses $1.8 \mu \mathrm{s}$ ) was the amber LED [peak wavelength $594 \mathrm{~nm}, 0.05 \mu \mathrm{mol}$ (quantum) $\mathrm{m}^{-2} \mathrm{~s}^{-1}$ ]. Actinic [white light; 400-750 nm; $500 \mu \mathrm{mol}$ (quantum) $\mathrm{m}^{-2} \mathrm{~s}^{-1}$ ] and pulse irradiations were provided by a halogen lamp (Osram 64255; $20 \mathrm{~W}$ ). The saturating pulse intensity amounted about $5,800 \mu \mathrm{mol}$ (quanta) $\mathrm{m}^{-2} \mathrm{~s}^{-1}$ and lasted $0.9 \mathrm{~s} . \mathrm{Fo}^{\prime}$ was measured after turning off the actinic light, by immediately irradiating the leaf for $3 \mathrm{~s}$ with a far red emitting diode (wavelength $735 \mathrm{~nm}$ ) with about $15 \mathrm{~W} \mathrm{~m}^{-2}$. The following parameters were estimated: $\mathrm{F}^{\prime} \mathrm{v} / \mathrm{F}^{\prime} \mathrm{m}, \mathrm{qP}$ and $\Phi_{\mathrm{PSII}}$ (Genty et al. 1989; Schreiber et al. 1994; Lichtenthaler et al. 2005).

\section{Measurements of PSII photoinhibition}

The response of PSII to strong illumination was carried out after the development of the second leaf. The fluorescence quenching and current photochemical efficiency of PSII were measured with a FMS2. First, seedlings were adapted ( $5 \mathrm{~min}$ ) to darkness to measure the minimum fluorescence (Fo), and then they were illuminated with strong irradiance (ca. $5,800 \mu \mathrm{mol}$ (quantum) $\mathrm{m}^{-2} \mathrm{~s}^{-1}$ ) to determine the maximum level of fluorescence $(\mathrm{Fm})$. Then, leaves were irradiated for $30 \mathrm{~min}$ with white light (halogen lamp) at 1,200 and 300 (control) $\mu \mathrm{mol}$ (quantum) $\mathrm{m}^{-2} \mathrm{~s}^{-1}$. Towards the end of this period, a pulse of saturating light was applied to determine $F^{\prime} \mathrm{m} .2$ min later the actinic light was switched off and the recovery of Fm followed for $60 \mathrm{~min}$ by applying pulses of saturating light every 1-2 min. The experimental protocol for the estimation of these components of qN was essentially the same as that described by Walters and Horton (1991). The non-photochemical quench $\mathrm{qN}$ is based on three major constituents: the energy quenching $\mathrm{qE}$, qT and $\mathrm{qI}$ caused by a photoinhibition of PSII units (Fork and Satoh 1986; Horton and Hauge 1988; van Wijk and van Hasselt 1993; Ting and Owens 1994; Ruban and Horton 1995; Owens 1996; Haldrup et al. 2001). qE is thought to occur in PSII antennae and there is evidence that it is regulated by the $\mathrm{pH}$ gradient across the thylakoid membrane and by the interconversion of pigments in the xanthophylls cycle (Owens 1996; Ting and Owens 1994; Ruban and Horton 1995). The photoinhibitory quenching qI is caused by the photoinhibition of PSII units (Greer et al. 1986; Baker 1994; Owens 1996). The state transition quenching qT is related to "state 1 " $\rightarrow$ "state 2 " transitions of the photosynthetic apparatus including phosphorylation of the mobile light-harvesting protein LHC2.

Relaxation of qN was assumed to consist of kinetically distinct phases: rapid, medium and slow (Walters and Horton 1991). Slow relaxing $\mathrm{qN}$ was estimated by plotting $\Delta \mathrm{Fm} / \mathrm{F}^{\prime} \mathrm{m}$ (nomenclature Johnson et al. 1993) on a logarithmic scale and extrapolating the slow phase of recovery back to the ' $y$ ' axis. The ' $y$ ' intercept represent the amount of $\mathrm{qN}$ due to the slowly relaxing component. This value was then subtracted from the remaining points and the process repeated to obtain the values of $\mathrm{qN}$ due to the medium and fast phases. The fast, medium and slow components are defined as: $\left(\Delta \mathrm{Fm} / \mathrm{F}^{\prime} \mathrm{m}\right) \mathrm{f}$, an estimate of $\mathrm{qE}$ 
quenching $\left(\Delta \mathrm{Fm} / \mathrm{F}^{\prime} \mathrm{m}\right) \mathrm{m}$, an estimate of $\mathrm{qT}$ and $\mathrm{qE}$ quenching, and $\left(\Delta \mathrm{Fm} / \mathrm{F}^{\prime} \mathrm{m}\right) \mathrm{s}$, estimates of longer term photoinhibitory quenching. The measurements were carried on seedlings which were grown up from seeds incubated in water and in a ZEN solution $\left(4 \mathrm{mg} \mathrm{dm}^{-3}\right)$.

\section{Statistical analysis}

All data were analyzed using Statistica 8.0 software (Statsoft Inc., Tulsa, OK, USA). Appropriate numbers of replications and tests used are indicated in tables and their descriptions. The significance of differences of mean values taken from data with normal arrangement (ShapiroWilk test) was tested using the Student's $t$ test and multiple Duncan's test. For data that did not respond to that criterion, the Mann-Whitney $U$ test was used.

\section{Results}

The direct effect of ZEN on the photochemical activity of PSII in leaf discs

A slow decrease in the photochemical activity of PSII in leaf discs for the first $48 \mathrm{~h}$ of immersing them in water, and a significant one after $72 \mathrm{~h}$ were being seen (Table 1 ). That is why in the next series of measurements leaf discs were incubated in ZEN solutions only for $48 \mathrm{~h}$ (Table 2). The treatment of wheat leaf discs with ZEN at concentrations $0.5,1$ and $2 \mathrm{mg} \mathrm{dm}^{-3}$ decreased the density of active reaction centers per cross section (RC/CS) and energy

Table 1 The influence of the incubation time of wheat and soybean leaf discs in water (without ZEN) on parameters obtained from the JIP test per excited cross section (CS)

\begin{tabular}{cccccc}
\hline $\begin{array}{l}\text { Time } \\
\text { (hours) }\end{array}$ & RC/CS & ABS/CS & TRo/CS & ETo/CS & DIo/CS \\
\hline Wheat & & & & & \\
$0^{\mathrm{a}}$ & $822.2 \mathrm{a}$ & $1,970.2 \mathrm{a}$ & $1,480.2 \mathrm{a}$ & $845.2 \mathrm{a}$ & $490.0 \mathrm{a}$ \\
24 & $769.6 \mathrm{~b}$ & $1,850.1 \mathrm{ab}$ & $1,389.7 \mathrm{ab}$ & $763.8 \mathrm{~b}$ & $460.4 \mathrm{ab}$ \\
48 & $740.6 \mathrm{~b}$ & $1,841.9 \mathrm{~b}$ & $1,371.3 \mathrm{~b}$ & $757.7 \mathrm{~b}$ & $470.6 \mathrm{ab}$ \\
72 & $574.3 \mathrm{c}$ & $1,215.1 \mathrm{c}$ & $765.4 \mathrm{c}$ & $375.3 \mathrm{c}$ & $449.7 \mathrm{~b}$ \\
Soybean & & & & & \\
$0^{\mathrm{a}}$ & $733.3 \mathrm{a}$ & $1,833.9 \mathrm{a}$ & $1,335.1 \mathrm{a}$ & $712.9 \mathrm{a}$ & $498.8 \mathrm{a}$ \\
24 & $715.3 \mathrm{ab}$ & $1,787.3 \mathrm{a}$ & $1,302.9 \mathrm{ab}$ & $685.3 \mathrm{~b}$ & $484.4 \mathrm{a}$ \\
48 & $704.6 \mathrm{~b}$ & $1,761.3 \mathrm{a}$ & $1,273.4 \mathrm{~b}$ & $668.5 \mathrm{~b}$ & $487.9 \mathrm{a}$ \\
72 & $528.8 \mathrm{c}$ & $1,109.4 \mathrm{~b}$ & $687.8 \mathrm{c}$ & $323.4 \mathrm{c}$ & $421.6 \mathrm{~b}$ \\
\hline
\end{tabular}

Means followed by the same letters within columns (separately for wheat and soybean) do not differ significantly according to the Duncan's multiple range test $(\alpha=0.05), n=18-24$

${ }^{a}$ The measurement performed just before the immersion of discs in water fluxes for absorption (ABS/CS), trapping (TRo/CS) and electron transport (ETo/CS). This was accompanied by the inhibition of the activity of the $\mathrm{O}_{2}$ evolving centers (OEC) by ZEN. The energy flux in PSII was inhibited most significantly by ZEN at a concentration of $0.5 \mathrm{mg} \mathrm{dm}^{-3}$ (a decrease in the values of ABS/CS, TRo/CS and ETo/CS by about $33-51 \%$ ), while $\mathrm{ZEN}$ at the lowest concentration $\left(0.25 \mathrm{mg} \mathrm{dm}^{-3}\right)$ showed the lowest effect. The effects of ZEN action on soybean were opposite to those observed for wheat. The values RC/CS, ABS/CS, TRo/CS and ETo/CS significantly increased with the increase in ZEN concentration, reaching a maximum at $1 \mathrm{mg} \mathrm{dm}^{-3}$. The increase in the values of these JIP parameters at the optimum ZEN concentration amounted from ca. 30 to $86 \%$ in comparison with the control. The incubation of leaves in ZEN solutions also resulted in an increase in the activity of OEC by about $29 \%$.

The after-effect of ZEN on the photochemical activity of seedlings

The pre-sowing seed incubation in ZEN solution did not induce statistically significant after-effects in efficiency of excitation energy capture by open PSII reaction centers $\left(\mathrm{F}^{\prime} \mathrm{v} / \mathrm{F}^{\prime} \mathrm{m}\right)$, photochemical quenching of chlorophyll $a$ fluorescence $(\mathrm{qP})$ and the quantum yield of $\mathrm{PS}$ II electron transport $\left(\Phi_{\text {PSII }}\right)$ in wheat seedlings (Table 3 ). The lack of influence of ZEN on the photochemical activity of PSII in the light was observed at both phases, i.e. the second and fourth leaf. In contrast, the incubation of soybean seeds in ZEN solutions increased the values of $\mathrm{F}^{\prime} \mathrm{v} / \mathrm{F}^{\prime} \mathrm{m}$ by about $20 \%$ and that of $\Phi_{\text {PSII }}$ by more than $22 \%$ for the both developmental stages.

The effects of ZEN on different physiological processes under stress conditions

\section{Photoinhibition of PSII}

The plants used for photoinhibition studies were in a good form and that is why the maximum photochemical efficiency of PSII (Fv/Fm) was high (from 0.808 to 0.809). All components of non-photochemical quenching (qI, qT and $\mathrm{qE})$ for wheat and soybean were several times higher during strong illumination (1,200 $\mu \mathrm{mol}$ (quantum) $\left.\mathrm{m}^{-2} \mathrm{~s}^{-1}\right)$ than that during weak one $(300 \mu \mathrm{mol}$ (quantum) $\mathrm{m}^{-2} \mathrm{~s}^{-1}$ ) (Table 4). The influence of the pre-sowing seed incubation in ZEN solutions on the non-photochemical quench and the efficiency of photochemical reactions in PSII $\left(\mathrm{F}^{\prime} \mathrm{v} / \mathrm{F}^{\prime} \mathrm{m}, \mathrm{qP}\right.$ and $\left.\Phi_{\mathrm{PSII}}\right)$ was not observed during weak illumination, but only during that of strong one for both species. The incubation of wheat kernels in ZEN induced, at the high PFD, a decrease in the value of the quenching 
Table 2 The influence of the incubation of wheat and soybean leaf discs in ZEN solutions on parameters obtained from the JIP test per excited cross section (CS)

\begin{tabular}{|c|c|c|c|c|c|c|}
\hline $\mathrm{ZEN}\left(\mathrm{mg} \mathrm{dm}^{-3}\right)$ & $\mathrm{RC} / \mathrm{CS}$ & $\mathrm{ABS} / \mathrm{CS}$ & TRo/CS & $\mathrm{ETo} / \mathrm{CS}$ & $\mathrm{DIo} / \mathrm{CS}$ & OEC \\
\hline \multicolumn{7}{|l|}{ Wheat } \\
\hline 0.00 & 686.7 & $2,066.2$ & $1,467.9$ & 849.3 & 598.3 & 100.0 \\
\hline \multicolumn{7}{|c|}{ Changes in value expressed as percentages of the control } \\
\hline 0.25 & +5.1 & -6.9 & -7.4 & $-12.6^{*}$ & -5.4 & $-28.6^{* *}$ \\
\hline 0.50 & $-32.0 * *$ & $-33.5^{* *}$ & $-41.9 * *$ & $-50.7 * *$ & $-12.7 *$ & $-48.1 * *$ \\
\hline 1.00 & $-16.6 * *$ & $-20.1 * *$ & $-26.5 * *$ & $-30.7 * *$ & -4.5 & $-30.5^{* *}$ \\
\hline 2.00 & $-18.1 * *$ & $-19.3 * *$ & $-24.7 * *$ & $-27.3 * *$ & -6.1 & $-12.0 *$ \\
\hline \multicolumn{7}{|l|}{ Soybean } \\
\hline 0.00 & 698.8 & $2,388.0$ & $1,840.4$ & $1,399.5$ & 547.6 & 100.0 \\
\hline \multicolumn{7}{|c|}{ Changes in value expressed as percentages of the control } \\
\hline 0.25 & $+12.9^{*}$ & +2.7 & $+12.4 *$ & $+39.1 * *$ & $-12.1 *$ & $+80.0 * *$ \\
\hline 0.50 & $+26.7 * *$ & +5.9 & $+17.1 *$ & $+26.9 * *$ & $-11.3 * *$ & -0.7 \\
\hline 1.00 & $+71.3^{* *}$ & $+29.2 * *$ & $+54.0 * *$ & $+86.0 * *$ & -8.7 & $+28.8 * *$ \\
\hline 2.00 & $+57.0^{* *}$ & $+21.4 * *$ & $+44.3 * *$ & $+66.8 * *$ & $-13.8^{*}$ & $+12.4^{*}$ \\
\hline
\end{tabular}

The discs were incubated in water (control) and in ZEN solutions for $48 \mathrm{~h}$. The statistically significant differences $(* P<0.05$ and $* * P<0.001)$ in comparison with the control have been marked with an asterisks-on the basis of the Student's $t$ test, $n=20$

Table 3 The after-effect of preceding sowing incubation of wheat and soybean seeds in ZEN solution $\left(4 \mathrm{mg} \mathrm{dm}^{-3}\right.$ ) on the parameters of photochemical activity of PSII at different developmental stages of seedlings

\begin{tabular}{llllc}
\hline $\begin{array}{l}\text { Developmental } \\
\text { phase }\end{array}$ & ZEN $\left(\mathrm{mg} \mathrm{dm}^{-3}\right)$ & $\mathrm{F}^{\prime} \mathrm{v} / \mathrm{F}^{\prime} \mathrm{m}$ & $\mathrm{qP}$ & $\Phi_{\mathrm{PSII}}$ \\
\hline Wheat & & & & \\
2 leaves & 0.0 & & & \\
& 4.0 & 0.452 & 0.354 & 0.160 \\
& $\% \%^{\mathrm{a}}$ & 0.463 & 0.335 & 0.155 \\
4 leaves & 0.0 & +2.4 & -5.4 & -3.1 \\
& 4.0 & 0.412 & 0.432 & 0.178 \\
& $\% \%$ & 0.435 & 0.421 & 0.183 \\
Soybean & & +5.6 & -2.5 & +2.9 \\
2 leaves & 0.0 & & & \\
& 4.0 & 0.408 & 0.305 & 0.124 \\
& $\% \%$ & 0.487 & 0.318 & 0.155 \\
4 leaves & 0.0 & $+19.4^{*}$ & 4.3 & $+24.5^{*}$ \\
& 4.0 & 0.407 & 0.313 & 0.127 \\
& $\% \%$ & 0.493 & 0.317 & 0.156 \\
& & $+21.1^{*}$ & 1.3 & $+22.6^{*}$ \\
\hline
\end{tabular}

Measurements carried out on the highest well-developed leaf at PFD $500 \mu \mathrm{mol}$ (quantum) $\mathrm{m}^{-2} \mathrm{~s}^{-1}$

a The change in the value expressed as percentage of the control (seedlings grown from seeds soaked in water). A statistically significant differences $(P<0.05)$ have been marked with an asterisks- on the basis of the Student's $t$ test, $n=8$

component qI by $16.9 \%$ in comparison with the control (plants incubated in water). The lower value of qI can be a result of a lower level of photoinhibitory injuries to PSII. The consequence of this could be a considerable decrease in the inhibition of photochemical reactions in PSII caused by ZEN. Due to this effect, the values of $\mathrm{F}^{\prime} \mathrm{v} / \mathrm{F}^{\prime} \mathrm{m}, \mathrm{qP}$ and $\Phi_{\mathrm{PSII}}$ were significantly higher in plants incubated in ZEN than in the control. The decrease in the photoinhibitory injuries to PSII was possibly due to safe scattering of the energy excess which was reflected as an increase in qT value by $17.2 \%$ and $\mathrm{qE}$ by $17.3 \%$. A similar pattern of plant response to ZEN was also observed for soybean. At strong illumination, quenching $\mathrm{qI}$ was, after the incubation of seeds in ZEN, by $26.2 \%$ lower than that in the control. The protective action of ZEN could be explained by the $29.5 \%$ increase in the dissipation of energy through the component qE. Similarly as in wheat, the efficiency of PSII in soybean was, due to the weakening of photoinhibitory injuries, higher than for the control. This resulted in plants maintaining higher values of $\mathrm{F}^{\prime} \mathrm{v} / \mathrm{F}^{\prime} \mathrm{m}, \mathrm{qP}$ and $\Phi_{\mathrm{PSII}}$ at strong illumination.

Growth of seedlings during salt stress

At its highest concentrations ZEN ( 2 and $4 \mathrm{mg} \mathrm{dm}^{-3}$ ) stimulated the coleoptile and root elongation, but decreased mass accumulation in roots during wheat germination in water without $\mathrm{NaCl}$ (control) (Table 5). For soybean grown under the same conditions ZEN treatment at higher concentrations led consequently to increased rate of coleoptile elongation and of mass accumulation. When values of the osmotic potential $\left(\Psi_{0}\right)$ were gradually decreased by the addition of $\mathrm{NaCl}$, a stronger inhibition of the growth of seedlings was observed for both wheat and soybean. ZEN at some concentrations decreased the level of growth 
Table 4 The influence of seed incubation in ZEN solution $\left(4 \mathrm{mg} \mathrm{dm}^{-3}\right)$ on the photochemical efficiency of the reaction in PSII in wheat and soybean leaves as dependent on the intensity of plant illumination (30 $\mathrm{min}$ ) before measurements

$\begin{array}{lllll}\frac{1,200 \mu \mathrm{mol}(\text { quantum }) \mathrm{m}^{-2} \mathrm{~s}^{-1}}{\mathrm{ZEN}\left(\mathrm{mg} \mathrm{dm}^{-3}\right)} & \text { Significant of difference } & \frac{300 \mu \mathrm{mol}(\text { quantum }) \mathrm{m}^{-2} \mathrm{~s}^{-1}}{\mathrm{ZEN}\left(\mathrm{mg} \mathrm{dm}^{-3}\right)} & \frac{\text { Significant of difference }}{4.0}\end{array}$

\begin{tabular}{lllllll}
\hline Wheat & & & & & & \\
qI & 0.657 & 0.791 & $*$ & 0.122 & 0.121 & n.s. \\
$\mathrm{qT}$ & 0.751 & 0.641 & $*$ & 0.184 & 0.178 & n.s. \\
$\mathrm{qE}$ & 1.788 & 1.524 & $*$ & 0.316 & 0.321 & n.s. \\
Total & 3.196 & 2.956 & $*$ & 0.622 & 0.620 & n.s. \\
$\mathrm{F}^{\prime} \mathrm{v} / \mathrm{F}^{\prime} \mathrm{m}$ & 0.530 & 0.455 & $*$ & 0.723 & 0.725 & n.s. \\
$\mathrm{qP}$ & 0.515 & 0.475 & $* *$ & 0.812 & 0.815 & n.s. \\
$\Phi_{\mathrm{PSII}}$ & 0.273 & 0.216 & $*$ & 0.587 & 0.591 & n.s. \\
Soybean & & & & & & \\
$\mathrm{qI}$ & 0.698 & 0.946 & $* *$ & 0.117 & 0.109 & n.s. \\
$\mathrm{qT}$ & 0.575 & 0.557 & n.s. & 0.034 & 0.049 & n.s. \\
$\mathrm{qE}$ & 1.637 & 1.264 & $*$ & 0.213 & 0.222 & n.s. \\
Total & 2.910 & 2.767 & $*$ & 0.364 & 0.380 & n.s. \\
$\mathrm{F}^{\prime} \mathrm{v} / \mathrm{F}^{\prime} \mathrm{m}$ & 0.517 & 0.434 & $*$ & 0.723 & 0.728 & n.s. \\
$\mathrm{qP}$ & 0.520 & 0.451 & $*$ & 0.904 & 0.899 & n.s. \\
$\Phi_{\mathrm{PSII}}$ & 0.269 & 0.195 & $*$ & 0.654 & 0.654 & n.s.
\end{tabular}

Measurements were carried out on second well-developed leaves of wheat and soybean. The statistically significant $(* P<0.05, * * P<0.001)$ differences obtained at ZEN concentrations 4 and $0.0 \mathrm{mg} \mathrm{dm}^{-3}$ have been marked with asterisks—on the basis of the Student's $t$ test, $n=9$ n.s. differences statistically not significant

inhibition by $\mathrm{NaCl}$ in wheat. At $\Psi_{0}$ values of -0.25 and $-0.5 \mathrm{MPa}, \mathrm{ZEN}$ at the highest concentrations weakened the inhibition of mass accumulation and elongation of coleoptiles and the roots of wheat. At the lowest osmotic potential $(-1.0 \mathrm{MPa}), \mathrm{ZEN}$ limited the decrease in the mass accumulation in wheat coleoptile, but did not have any effect on the root mass and elongation of coleoptile and roots. Within the range of $\mathrm{NaCl}$ concentrations tested, $\mathrm{ZEN}$ at the concentration of $2.0 \mathrm{mg} \mathrm{dm}^{-3}$ exerted the strongest effect protecting wheat against salt stress. In its presence the mass of coleoptile and roots was on average about $103 \%$ higher than in the control, and the length of coleoptile and roots was higher by about 91 and $36 \%$, respectively.

For soybean, the effects of ZEN under salt stress were more complicated. At some values of $\Psi_{0}, \mathrm{ZEN}$ did not affect the mass accumulation in roots $(-0.25 \mathrm{MPa})$ and coleoptile elongation $(-0.5$ and $-1.0 \mathrm{MPa})$. In addition, at the most negative osmotic potential, ZEN at some concentrations ( 2 and $4 \mathrm{mg} \mathrm{dm}^{-3}$ ) inhibited the ability of coleoptile and roots of soybean to accumulate mass and the elongation of roots. On an average, for all $\mathrm{NaCl}$ concentrations only ZEN at a concentration of $2.0 \mathrm{mg} \mathrm{dm}^{-3}$ showed a protective effect on the increment of soybean coleoptile mass. All the ZEN concentrations tested showed a protective effect on the mass increase and elongation of roots. In the presence of $\mathrm{ZEN}$ at those concentrations, the mass of coleoptile and roots and the length of roots were higher than that for the control by 40, 107 and 19\%, respectively.

\section{Discussion}

Photochemical activity of PSII

Owing to the lack of information on the mechanisms of ZEN action in plants, yet it is not possible to formulate clear and reliable view about the causes of the different responses of wheat and soybean leaf discs to zearalenone, as the photochemical activity of PSII was concerned (Table 2). As it is known ZEN contains several aromatic rings in its molecule (Urry et al. 1966) and that is why it is the most hydrophobic structure among such hormones as IAA, 2-4-D, kinetin, zeatin (Gzyl et al. 2004). It may be supposed that the leaf disc surfaces of both species tested differ in their hydrophobic interactions and therefore the different absorption rate of ZEN by cells occured. Another cause of the differing responses of PSII to ZEN in wheat and soybean could be its various affinity to receptors, that may be either non-specific (Olsen 1989) or specific ones (Wang and Meng 1993). In addition, the low solubility of 
Table 5 The influence of different concentrations of ZEN on the early growth of wheat and soybean seedlings as dependent on the osmotic potential of $\mathrm{NaCl}$ solutions
Means followed by the same letters within columns (separately for each osmotic potential) do not differ significantly according to the Duncan's multiple range test $(\alpha=0.05), n=15-20$

\begin{tabular}{|c|c|c|c|c|c|}
\hline \multirow{2}{*}{$\begin{array}{l}\text { Osmotic } \\
\text { potential (MPa) }\end{array}$} & \multirow{2}{*}{$\begin{array}{l}\mathrm{ZEN} \\
\left(\mathrm{mg} \mathrm{dm}^{-3}\right)\end{array}$} & \multicolumn{2}{|c|}{ Dry weight (mg) } & \multicolumn{2}{|c|}{ Length $(\mathrm{cm})$} \\
\hline & & Coleoptile & Roots & Coleoptile & Roots \\
\hline \multicolumn{6}{|l|}{ Wheat } \\
\hline \multirow[t]{4}{*}{0.00} & 0.00 & $13.32 \mathrm{a}$ & $22.57 \mathrm{a}$ & $9.77 \mathrm{~b}$ & $10.05 \mathrm{~b}$ \\
\hline & 0.25 & $12.77 \mathrm{a}$ & $20.74 \mathrm{ab}$ & $10.10 \mathrm{~b}$ & $10.84 \mathrm{ab}$ \\
\hline & 2.00 & $14.13 \mathrm{a}$ & $17.03 \mathrm{~b}$ & $13.32 \mathrm{a}$ & $11.35 \mathrm{a}$ \\
\hline & 4.00 & $13.90 \mathrm{a}$ & $17.44 \mathrm{~b}$ & $14.26 \mathrm{a}$ & $12.32 \mathrm{a}$ \\
\hline \multirow[t]{4}{*}{-0.25} & 0.00 & $5.83 \mathrm{~b}$ & $11.02 \mathrm{~b}$ & $4.01 \mathrm{~b}$ & $5.44 \mathrm{a}$ \\
\hline & 0.25 & $7.02 \mathrm{ab}$ & $19.47 \mathrm{a}$ & $4.06 \mathrm{~b}$ & $5.47 \mathrm{a}$ \\
\hline & 2.00 & $8.64 \mathrm{a}$ & $18.63 \mathrm{a}$ & $4.93 \mathrm{a}$ & $5.79 \mathrm{a}$ \\
\hline & 4.00 & $8.69 \mathrm{a}$ & $19.52 \mathrm{a}$ & $4.94 \mathrm{a}$ & $5.49 \mathrm{a}$ \\
\hline \multirow[t]{4}{*}{-0.50} & 0.00 & $0.38 \mathrm{~d}$ & $5.02 \mathrm{c}$ & $0.25 \mathrm{c}$ & $1.84 \mathrm{c}$ \\
\hline & 0.25 & $1.02 \mathrm{c}$ & $9.47 \mathrm{~b}$ & $0.47 \mathrm{c}$ & $2.67 \mathrm{bc}$ \\
\hline & 2.00 & $3.77 \mathrm{a}$ & $14.07 \mathrm{a}$ & $3.31 \mathrm{a}$ & $4.06 \mathrm{a}$ \\
\hline & 4.00 & $1.78 \mathrm{~b}$ & $11.93 \mathrm{ab}$ & $1.59 \mathrm{~b}$ & $3.13 \mathrm{~b}$ \\
\hline \multirow[t]{4}{*}{-1.00} & 0.00 & $0.02 \mathrm{~b}$ & $0.02 \mathrm{a}$ & $0.08 \mathrm{a}$ & $0.03 \mathrm{a}$ \\
\hline & 0.25 & $0.27 \mathrm{a}$ & $0.05 \mathrm{a}$ & $0.15 \mathrm{a}$ & $0.03 \mathrm{a}$ \\
\hline & 2.00 & $0.23 \mathrm{a}$ & $0.04 \mathrm{a}$ & $0.08 \mathrm{a}$ & $0.08 \mathrm{a}$ \\
\hline & 4.00 & $0.20 \mathrm{a}$ & $0.43 \mathrm{a}$ & $1.25 \mathrm{a}$ & $1.25 \mathrm{a}$ \\
\hline \multirow{4}{*}{$\begin{array}{l}\text { Mean for: }-0.25,-0.5 \\
\text { and }-1.0\end{array}$} & 0.00 & $2.08 \mathrm{~d}$ & $5.35 \mathrm{c}$ & $1.45 \mathrm{~b}$ & $2.44 \mathrm{~b}$ \\
\hline & 0.25 & $2.77 \mathrm{c}$ & $9.66 \mathrm{~b}$ & $1.56 \mathrm{~b}$ & $2.72 \mathrm{~b}$ \\
\hline & 2.00 & $4.21 \mathrm{a}$ & $10.91 \mathrm{a}$ & $2.77 \mathrm{a}$ & $3.31 \mathrm{a}$ \\
\hline & 4.00 & $3.56 \mathrm{~b}$ & $10.63 \mathrm{a}$ & $2.59 \mathrm{a}$ & $3.29 \mathrm{a}$ \\
\hline \multicolumn{6}{|l|}{ Soybean } \\
\hline \multirow[t]{4}{*}{0.00} & 0.00 & $6.64 \mathrm{c}$ & $12.98 \mathrm{a}$ & $1.67 \mathrm{c}$ & $13.17 \mathrm{a}$ \\
\hline & 0.25 & $7.83 \mathrm{bc}$ & $13.96 \mathrm{a}$ & $2.39 \mathrm{bc}$ & $13.01 \mathrm{a}$ \\
\hline & 2.00 & $11.79 \mathrm{a}$ & $12.64 \mathrm{a}$ & $3.97 \mathrm{a}$ & $13.88 \mathrm{a}$ \\
\hline & 4.00 & $10.03 \mathrm{ab}$ & $13.63 \mathrm{a}$ & $2.90 \mathrm{~b}$ & $13.18 \mathrm{a}$ \\
\hline \multirow[t]{4}{*}{-0.25} & 0.00 & $3.31 \mathrm{~b}$ & $10.24 \mathrm{a}$ & $0.73 \mathrm{~b}$ & $9.61 \mathrm{~b}$ \\
\hline & 0.25 & $3.45 \mathrm{ab}$ & $11.46 \mathrm{a}$ & $0.82 \mathrm{ab}$ & $11.72 \mathrm{a}$ \\
\hline & 2.00 & $4.25 \mathrm{a}$ & $11.27 \mathrm{a}$ & $0.89 \mathrm{a}$ & $10.19 \mathrm{ab}$ \\
\hline & 4.00 & $3.17 \mathrm{~b}$ & $10.03 \mathrm{a}$ & $0.79 \mathrm{ab}$ & $10.04 \mathrm{ab}$ \\
\hline \multirow[t]{4}{*}{-0.50} & 0.00 & $3.10 \mathrm{bc}$ & $6.20 \mathrm{~b}$ & $0.61 \mathrm{a}$ & $4.46 \mathrm{~b}$ \\
\hline & 0.25 & $2.74 \mathrm{c}$ & $8.35 \mathrm{a}$ & $0.61 \mathrm{a}$ & $7.00 \mathrm{a}$ \\
\hline & 2.00 & $4.17 \mathrm{a}$ & $8.62 \mathrm{a}$ & $0.61 \mathrm{a}$ & $7.18 \mathrm{a}$ \\
\hline & 4.00 & $3.21 \mathrm{~b}$ & $8.80 \mathrm{a}$ & $0.61 \mathrm{a}$ & $7.04 \mathrm{a}$ \\
\hline \multirow[t]{4}{*}{-1.00} & 0.00 & $2.52 \mathrm{~b}$ & $4.97 \mathrm{a}$ & $0.46 \mathrm{a}$ & $2.61 \mathrm{a}$ \\
\hline & 0.25 & $2.24 \mathrm{~b}$ & $4.12 \mathrm{ab}$ & $0.53 \mathrm{a}$ & $2.38 \mathrm{a}$ \\
\hline & 2.00 & $4.05 \mathrm{a}$ & $3.05 \mathrm{c}$ & $0.49 \mathrm{a}$ & $1.76 \mathrm{~b}$ \\
\hline & 4.00 & $1.94 \mathrm{c}$ & $3.71 \mathrm{bc}$ & $0.51 \mathrm{a}$ & $2.37 \mathrm{a}$ \\
\hline \multirow{4}{*}{$\begin{array}{l}\text { Means for: }-0.25,-0.5 \\
\text { and }-1.0\end{array}$} & 0.00 & $2.98 \mathrm{~b}$ & $3.72 \mathrm{~b}$ & $0.60 \mathrm{a}$ & $5.56 \mathrm{c}$ \\
\hline & 0.25 & $2.81 \mathrm{~b}$ & $7.98 \mathrm{a}$ & $0.65 \mathrm{a}$ & $7.03 \mathrm{a}$ \\
\hline & 2.00 & $4.16 \mathrm{a}$ & $7.65 \mathrm{a}$ & $0.66 \mathrm{a}$ & $6.38 \mathrm{~b}$ \\
\hline & 4.00 & $2.77 \mathrm{~b}$ & $7.51 \mathrm{a}$ & $0.64 \mathrm{a}$ & $6.48 \mathrm{~b}$ \\
\hline
\end{tabular}

ZEN in water is the cause of its transformation by the cell to a soluble form-glycoside. This phenomenon was observed in Arabidopsis thaliana (Berthillet et al. 2007). Yet it is, unfortunately, unknown whether this is the form of ZEN occurring in the studied species. The energy flow through photosystems involves chloroplast membranes and it is impossible to exclude the possibility that the cause of the observed ZEN effects could result from its interactions with those structures (Vianello and Macri 1978; Filek et al. 2002, 2007). 
The increase in photochemical activity of PSII in soybean seedlings after soaking of seeds in ZEN solutions (Table 3) proved similar to that in leaf discs incubated in ZEN solutions. These results are consistent with the earlier observations (Kościelniak et al. 2009) that ZEN treatment of plants was the resulted increase in photochemical activity of PSII at the early developmental stages in soybean. ZEN inhibited photochemical reactions in wheat discs, but did not affect PSII activity in wheat seedlings. The disappearance of the inhibitory photochemical reactions in wheat seedlings could be associated with ZEN 'dissolving' during the growth. The light conditions may be recognized as the decisive factor for the occurrence of positive responses of seedlings to ZEN, as photochemical changes in PSII in wheat and soybean were observed during strong illumination-1,200 $\mu \mathrm{mol}$ (quantum) $\mathrm{m}^{-2} \mathrm{~s}^{-1}$ (Table 4). On the other hand, an illumination of $500 \mu \mathrm{mol}$ (quantum) $\mathrm{m}^{-2} \mathrm{~s}^{-1}$, the stimulatory effect disappeared in wheat, and at $300 \mu \mathrm{mol}$ (quantum) $\mathrm{m}^{-2} \mathrm{~s}^{-1}$ also in soybean.

The stimulation of the activity of the photosynthesis by ZEN probably does not occur in all species. In the experiments with gram (Cicer arietinum L.) and mustard (Brassica juncea $\mathrm{L}$.) it was discovered that seed incubation caused after-effects such as a strong inhibition in the synthesis of chlorophylls $a, b$ and carotenoids (Kumar and Sinha 1995) and such a response was explained as a result of the disturbance in the pigment synthesis by restricting the growth hormone-induced synthesis of RNA, DNA and proteins in the leaf. Similarly, strong metabolism responses to ZEN were also observed in animals (Mueller et al. 2004, Boehme et al. 2009).

\section{Photoinhibitory reactions of PSII}

The data showing that preceding sowing incubation of seeds in ZEN solutions resulted in an increase in the nonphotochemical quenching ( $\mathrm{qE}, \mathrm{qT}$ ) during strong illumination for both species (Table 4) are consistent with the opinions of other authors (Fork and Satoh 1986; Horton and Hauge 1988; van Wijk and van Hasselt 1993; Ting and Owens 1994; Ruban and Horton 1995; Owens 1996; Haldrup et al. 2001) that such response may be recognized as the action of the first defense line for the photosynthetic apparatus against photoinhibitory injuries and other photooxidative ones. In our experiment it was observed that ZEN prevented photoinhibitory injuries during strong illumination due to the safe dissipation of the excess of absorbed light energy through mechanisms related to the development of $\mathrm{pH}$ gradient (qE) in thylakoids and phosphorylation of LHC2 (qT). A decrease due to the influence of ZEN on the photoinhibitory quenching enabled the maintenance of a more efficient course of reaction in PSII than in plants incubated before sowing in water.

The seedlings growth under salt stress

The stimulation of growth by ZEN has been also found earlier for wheat callus (Biesaga-Kościelniak 2001; Szechyńska-Hebda et al. 2007) as well as in wheat and rape seedlings (Biesaga-Kościelniak 2001). On the other hand, it was reported by Kumar and Sinha (1995) that in their experiment the same ZEN concentrations as those used in our experiment caused inhibition the elongation of the coleoptile and root in gram and mustard, and this response increased with ZEN concentration. The salt stress strongly limited the growth of seedlings, as was also reported in other papers concerning wheat and soybean (Ashraf and McNeily 1988; Luo et al. 2005; Soltani et al. 2006). ZEN protected via after-effects the process of wheat growth against the salt stress through decreasing the level of inhibition to the elongation process and mass accumulation in coleoptile and roots. The complicate nature of ZEN action under salt stress was revealed especially by the measurements in soybean. Depending on the water potential, ZEN did not affect the growth, inhibited it or protected this process against the stress consequences. The complex response of growth to the excess of $\mathrm{NaCl}$ can result from the fact that salt stress inhibits physiological processes by limiting the amount of water in tissues (Rauf et al. 2007) and through the toxic effects of $\mathrm{Na}^{+}$and $\mathrm{Cl}^{-}$ions (Yang and Blanchar 1993; Lacan and Durand 1996; Kurniadie and Redmann 1999) and ionic imbalance in leaves (Yeo et al. 1985). For the germinating soybean, $\mathrm{Cl}^{-}$ion is more toxic than $\mathrm{Na}^{+}$(Luo et al. 2005). It seems that the positive effect of ZEN on the intensity of seedling growth at the earlier phases of growth could be explained, among other, by its ability to increase the activity of $\alpha$-amylase and $\beta$-glucosidase (Vianello and Macri 1982).

\section{Conclusion}

On the basis of the results presented and discussed, it may be claimed that mycotoxin ZEN, which is harmful to many organisms, can stimulate the course of photochemical reactions in PSII as well as to support the process of growth under salt stress and to protect the photosynthetic apparatus of wheat and soybean seedlings against the consequences of strong illumination. As the use of ZEN in practice is concerned, it is necessary to consider the fact that the incubation of soybean seeds in ZEN solutions can be risky in salty soils with low water potential (ca. -1 MPa) because it can decrease the growth vigor. On the other hand in wheat ZEN could be harmful for the course of seed 
germination in non-stress conditions because it can inhibit the growth of roots. The consequence of those phenomena could be a decrease in plant productivity.

Open Access This article is distributed under the terms of the Creative Commons Attribution Noncommercial License which permits any noncommercial use, distribution, and reproduction in any medium, provided the original author(s) and source are credited.

\section{References}

Appenroth KJ, Teller S, Horn M (1996) Photophysiology of turion formation and germination in Spirodela polyrhiza. Biol Plant (Praha) 38:95-106

Appenroth KJ, Stöckel J, Srivastava A, Strasser RJ (2001) Multiple effects of chromate on the photosynthetic apparatus of Spirodela polyrhiza as probed by OJIP chlorophyll $a$ fluorescence measurements. Environ Pollut 115:49-64

Ashraf M, McNeily T (1988) Variability in salt tolerance of nine spring wheat cultivars. J Agron Crop Sci 160:14-21

Baker NR (1994) Chilling stress and photosynthesis. In: Foyer CH, Mullineaux PM (eds) Causes of photooxidative stress and amelioration of defense system plants. CRC Press, Boca Raton, pp 127-154

Biesaga-Kościelniak J, Marcińska I, Wędzony M, Kościelniak J (2003) Effect of zearalenone treatment in the production of wheat haploids via maize pollination system. Plant Cell Rep 21:1035-1039

Biesaga-Kościelniak J (1998) Investigation of the possibility of stimulating generative development of plants by exogenous zearalenone. Acta Physiol Plant 20:4-5

Biesaga-Kościelniak J (2001) Zearalenone as a new hypothetical regulator of plant growth and development. Monograph of Institute of Plant Physiology, Polish Academy of Sciences, Krakow, Poland, pp 1-135

Biesaga-Kościelniak J, Filek M (2010) Occurrence and physiology of zearalenone as a new plant hormone. In: Lichtfouse (ed) Sustainable agriculture reviews 3. Sociology, organic farming, climate change and soil science. Springer, Berlin, pp 419435

Biesaga-Kościelniak J, Janeczko A, Filek M, Dziurka M, Kościelniak $\mathrm{J}$ (2006a) Effect of zearalenone on the growth and productivity of crop plants I. Effectiveness of application of zearalenone on wheat production. Bib Frag Agron 11:53-54

Biesaga-Kościelniak J, Janeczko A, Filek M, Dziurka M, Kościelniak J (2006b) Effect of zearalenone on the growth and productivity of crop plants II. Effectiveness of application of zearalenone on soybean production. Bib Frag Agron 11:55-56

Boehme K, Simon S, Mueller SO (2009) Gene expression profiling in Ishikawa cells: a fingerprint for estrogen active compounds. Toxicol Appl Pharmacol 236:85-96

Chirife J, Resnik SL (1984) Unsaturated solutions of sodium chloride as reference sources of water activity at various temperatures. J Food Sci 49:1486-1488

Christensen CM, Nelson GH, Mirocha CJ (1965) Effect on the white rat uterus of toxic substance isolated from Fusarium. Appl Microbiol 13:653-659

Etienne M, Dourmad JY (1994) Effects of zearalenone or glucosinolates in the diet on reproduction in sows: a review. Livest Prod Sci 40:99-113

Filek M, Zembala M, Szechyńska-Hebda M (2002) The influence of phytohormones in zeta potential and electrokinetic charges of winter wheat cells. Z Naturforsch 57c:696-704
Filek M, Zembala M, Dudek A, Laggner P, Kriechbaum M (2007) Electric and structural studies of hormone interaction with chloroplast envelope membranes isolated from vegetative and generative rape. J Plant Physiol 164:861-867

Fork DC, Satoh K (1986) The control by state transitions of the distribution of excitation energy in photosynthesis. Annu Rev Plant Physiol 37:335-361

Fu YF, Meng FJ (1994) Zearalenone in growth and development of winter wheat. Acta Agron Sin (Chinese, Engl Summ) 20(3):271-276

Fu YF, Han ZY, Zhao DG, Meng FJ (2000) Zearalenone and flower bud formation in thin-cell layers of Nicotiana tabacum L. Plant Growth Regul 30:271-274

Genty B, Briantais JM, Baker NR (1989) The relationship between the quantum yield of photosynthetic electron transport and quenching of chlorophyll fluorescence. Biochim Biophys Acta 990:87-92

Greer DH, Berry JA, Björkman O (1986) Photoinhibition of photosynthesis in intact bean leaves: role of light and temperature, and requirement of chloroplast-protein synthesis during recovery. Planta 168:253-260

Gzyl B, Filek M, Dudek A (2004) Influence of phytohormones on polar and hydrophobic parts of mixed phospholipid monolayers at water/air interface. J Colloid Interface Sci 269:153-157

Haldrup A, Jensen PE, Lunde C, Scheller HV (2001) Balance of power: a view of the mechanism of photosynthetic state transitions. Trends Plant Sci 6:301-305

Hassen W, Ayed-Boussema I, Oscoz AA, Lopez AC, Bacha H (2007) The role of oxidative stress in zearalenone-mediated toxicity in Hep G2 cells: oxidative DNA damage, glutathione depletion and stress proteins induction. Toxicology 232:294-302

Hoagland DR, Arnon DI (1938) The water-culture method for growing plants with out soil. Univ Calif Exp Sta Cir 347

Horton P, Hauge A (1988) Studies on the induction of chlorophyll fluorescence in barley protoplasts IV. Resolution of nonphotochemical quenching. Biochim Biophys Acta 932:107-115

Johnson GN, Young AJ, Scholes AJ, Horton P (1993) The dissipation of excess excitation energy in British plant species. Plant Cell Environ 16:673-679

Kościelniak J, Biesaga-Kościelniak J, Janeczko A, Filek W, Kalaji HM (2009) Can the Giberella zeae toxin zearalenone affect the photosynthetic productivity and increase yield formation in spring wheat and soybean plants? Photosynthetica 47(4):586-594

Kumar N, Sinha KK (1995) Effect of zearalenone on some physiological and biochemical processes of gram and mustard seeds. In: Roy AK, Sinha KK (eds) Recent advances in phytopathological researches. M.D. Publications PVT Ltd., New Delhi, pp 149-162

Kurniadie D, Redmann RR (1999) Growth and chloride accumulation in Glycine max treated with excess $\mathrm{KCl}$ in solution culture. Commun Soil Sci Plant Anal 30:699-709

Lacan D, Durand M (1996) Na+ and K+ exchange at the xylem/ symplast boundary. Plant Physiol 110:705-711

Lazár D (1999) Chlorophyll a fluorescence induction. Biochim Biophys Acta 1412:1-28

Lazár D, Pospíśil P (1999) Mathematical simulation of chlorophyll a fluorescence rise measured with 3-(3', 4'-dichlorophenyl)-1, 1 dimethylurea-treated barley leaves at room and high temperatures. Eur Biophys J 28:468-477

Lichtenthaler HK, Buschmann C, Knapp M (2005) How to correctly determine the different chlorophyll fluorescence parameters and the chlorophyll fluorescence decrease ratio RFd of leaves with the PAM fluorometer. Photosynthetica 43(3):379-393

Luo Q, Yu B, Liu Y (2005) Differential sensitivity to chloride and sodium ions in seedlings of Glycine max and $G$. soya under $\mathrm{NaCl}$ stress. J Plant Physiol 162:1003-1012 
Meng FJ, Han YZ, Que YM, Wang H (1992) Zearalenone, a key substance controlling plant development. In: Karssen CM, Van Loon LC, Vreuggdennilcedes D (eds) Advances in plant regulation. Kluwer, Dordrecht, pp 291-297

Mueller SO, Simon S, Chae K, Metzler M, Korach KS (2004) Phytoestrogens and their human metabolites show distinct agonistic and antagonistic properties on estrogen receptor alpha (ERalpha) and ERbeta in human cells. Toxicol Sci 80:14-25

Olsen M (1989) Metabolism of zearalenone in farm animals. In: Chelkowski J (ed) Fusarium: mycotoxins taxonomy and pathogenicity. Elsevier, Amsterdam, pp 167-177

Owens TG (1996) Processing of excitation energy by antenna pigments. In: Baker NR (ed) Photosynthesis and environment. Kluwer, Dordrecht, pp 1-24

Price WD, Lowell RA, McChsney DG (1993) Naturally occurring toxins in feedstuffs. J Anim Sci 71:2556-2562

Rauf M, Munir M, Hassan M, Ahmad M, Afzal M (2007) Performance of wheat genotypes under osmotic stress at germination and early seedling growth stage. Afr J Biotech 6(8):971-975

Ruban AV, Horton P (1995) An investigation of sustained component of nonphotochemical quenching of chlorophyll fluorescence in isolated spinach chloroplasts and leaves of spinach. Plant Physiol 108:721-726

Schreiber U, Bilger W, Neubauer C (1994) Chlorophyll fluorescence as a nonintrusive indicator for rapid assessment of in vivo photosynthesis. In: Schultze ED, Caldwell MM (eds) Ecophysiology of photosynthesis. Springer, Berlin, pp 49-70

Soltani A, Gholipoor M, Zeinali E (2006) Seed reserve utilization and seedling growth of wheat as affected by drought and salinity. Environ Exp Bot 55:195-200

Srivastava A, Strasser RJ (1977) Constructive and destructive actions of light on the photosynthetic apparatus. J Sci Indus Res 56:133-148

Stob M, Baldwin RS, Tuite J, Andrews FN, Gillette KG (1962) Isolation of an anabolic uterotrophic compound from corn infected with Giberella zeae. Nature 196:1318

Strasser BJ, Strasser RJ (1995) Measuring fast fluorescence transients to address environmental questions: the JIP test. In: Mathis P (ed) Photosynthesis: from light to biosphere. Kluwer, Dordrecht, pp 977-980

Strasser RJ, Srivatava A, Tsimilli-Michael M (2000) The fluorescence transient as tool to characterize and screen photosynthetic samples. In: Yunus M, Pathre U, Mohanty P (eds) Probing photosynthesis: mechanism, regulation and adaptation. Taylor \& Francis, Bristol, pp 45-483

Szechyńska-Hebda M, Skrzypek E, Dąbrowska E, Biesaga-Kościelniak J, Filek M, Wędzony M (2007) The role of oxidative stress induced by growth regulators in the regeneration process of wheat. Acta Physiol Plant 329:327-337

Ting CS, Owens TG (1994) The effects of excess irradiance on photosynthesis in the marine diatom Phaeodactylum tricornutum. Plant Physiol 106:763-770

Urry WH, Wehrmeister HL, Hodge EB, Hidy PH (1966) The structure of zearalenone. Tetrahedron Lett 28:3109-3114

van Wijk KJ, van Hasselt PR (1993) Photoinhibition of photosystem II in vivo is preceded by down-regulation through light-induced acidification of the lumen: consequences for the mechanism of photoinhibition in vivo. Planta 190:359-368

Vianello A, Macri F (1978) Inhibition of plant cell membrane transport phenomena induced by zearalenone F-2. Planta 143:51-57

Vianello A, Macri F (1982) Zearalenone enhances $\alpha$-amylase and $\beta$ glucosidase activity of germinating maize seeds. Phytopath Medit 21(2):86-88

Walters RG, Horton P (1991) Resolution of components of nonphotochemical chlorophyll fluorescence quenching in barley leaves. Photosynth Res 27:121-133

Wang H, Meng FJ (1993) Studies on zearalenone binding protein in the vernalized seeds of winter wheat (Triticum aestivum L.). Chin J Bot 5:65-72

Yang J, Blanchar RW (1993) Differentiating chloride susceptibility in Glycine max. Agron J 85:880-885

Yeo AR, Caporn SJM, Flowers TJ (1985) The effect of salinity upon photosynthesis in rice (Oryza sativa L.); gas exchange by individual leaves in relation to their salt content. J Exp Bot 36:1240-1248 